\title{
Innovative approaches to identifying the relationship between the distribution of the concentration of enzymes in the blood serum and skeletal muscle tissue of rats
}

\author{
Pavel Boriskin ${ }^{1}$, Olga Gulenko ${ }^{2}$, Anatoliy Deviatkin ${ }^{1}$, Rufia Karimova ${ }^{1}$, Olga Pavlova ${ }^{3, *}$ \\ ${ }^{1}$ Kazan State Academy of Veterinary Medicine named after N.E. Bauman, st. Siberian tract, 35, \\ Kazan, 420074, Republic of Tatarstan, Russia \\ ${ }^{2}$ Private institution educational organization of higher education "Medical University "Reaviz", \\ st.Chapaevskaya, 227, Samara, 443099, Russia \\ ${ }^{3}$ LLC «TestGen», 44th passage Engineering, 9, office 13, Ulyanovsk, 432072, Russia
}

\begin{abstract}
One of the reasons for the increase in disability and mortality among the working population is cardiovascular diseases. Long-term studies of the nature of diseases belonging to this group - hypertension, renovascular and malignant arterial hypertension, dyslipidemia, diabetic and dilatational cardiomyopathy, atherosclerosis, ischemic heart disease show that the main cause of pathogenesis is the formation of oxidative stress under the influence of internal and external environmental factors. Mismatch between the processes of free-radical oxidation caused by such active oxygen species as superoxide-anion radical, hydroxide-radical radical, lipid radical, hydrogen peroxide, peroxynitrite, chloric acid and the capabilities of the antioxidant system leads to a disruption of the functional activity of cell structures, displacement of homeostatic balance in the body. Despite the rather deep study of cardiovascular system pathologies, data on the functional activity of myocardial cells under destructive effects and oxidative stress are still insufficient.The article presents the study of the interrelation of the concentration distribution of enzymes of the lipidantioxidant peroxidation system in blood serum and skeletal muscle tissue of white non-pedigree rats. By means of Spearman, Gamma and Kendel Tau correlation coefficients it was revealed a reliable presence of a weak force of inverse correlation between the concentration of catalase in blood serum and skeletal muscle (Spearman $\mathrm{R}=-0.21$ at $\mathrm{p} \leq 0.011749$, Gamma $=$ -0.14 at $\mathrm{p} \leq 0.010977$; Kendall Tau $=-0.14$ at $\mathrm{p} \leq 0.010977$ ).
\end{abstract}

\section{Introduction}

Adaptation of warm-blooded organisms to various factors, including muscle activity, is one of the main physiological problems. In vivo, motor activity acts as a powerful health factor that enhances the functionality of various physiological systems. It has been established that moderate physical activity of aerobic orientation has a positive effect on the respiratory,

\footnotetext{
*Corresponding author: casiopeya13@mail.ru
} 
cardiovascular and other systems of the body. At the same time, for normal functioning of the body and preservation of health a certain "dose" of motor activity is required [1].

Motor activity is one of the main factors determining the level of metabolic processes of the body and the state of its bone, muscle and cardiovascular systems. Many studies have found that adequate physical activity increases the body's resistance to oxidative stress, which is a state of hyperproduction of active oxygen species (AOS) due to increased functional capacity of oxygen transport systems, mitochondrial system, as well as the development of adaptive changes in the system POL-AO. Lipid peroxidation (LPO) is a chain-like process that continuously increases power over time, alters all stages of metabolism and has global functional significance.

In normal conditions, through the mechanism of LPO synthesis is carried out to support the body's vital functions, such as the synthesis of prostaglandins, the synthesis of certain steroid hormones, and regulates the activity of membrane-dependent enzymes of the endoplasmic system, the intensity of oxidative phosphorylation in mitochondria, membrane permeability, cell division, cholesterol metabolism, generation and conduction of nerve impulses.

Activation of POL processes, accompanying intensive physical activity, can cause significant disturbances in the work of various organs and systems, and thus offset the positive impact of physical activity on health. Strengthening of POL processes against the background of decrease in antioxidant protection leads to destruction of lipids, proteins and nucleic acids molecules, contributes to the development of peroxidation syndrome, which causes damage to membranes, inactivation of enzymes, destabilization of cell division and differentiation processes, as well as accumulation of inert biopolymers. For example, malonedialdehyde (MDA) has a toxic effect and causes mitochondrial dysfunction. Strengthening of POL processes is a natural step in the formation of adaptation syndrome and is associated with the regeneration processes of the body.

Motor activity is one of the main factors determining the level of metabolic processes of the body and the state of its bone, muscle and cardiovascular systems. Many studies have found that adequate physical activity increases the body's resistance to oxidative stress by increasing the functional capacity of oxygen transport systems, mitochondrial system, as well as the development of adaptive changes in the system of lipid peroxidation antioxidants (POL-AO). At the same time, it is known that the activation of lipid peroxidation (LPO), which accompanies intensive physical activity, can cause significant disturbances in the work of various organs and systems, and thus offset the positive impact of physical activity on health. The main reasons for the increase in free radical oxidation in intensive muscle work are insufficient oxygen supply and excessive activation of the sympatoadrenal system $[1,2,3,4]$.

Adjustment of the POL system occurs due to the complex properties of lipid bilayer cell membranes, which selectively passes ROS and radical intermediates to polyene acyls of phospholipids.

Increasing the rate of free radical oxidation in the body is a rather destructive process, which is reflected in the composition of blood serum $[5,6,7]$. In general, the change in the parameters of the POL system reflects the change in the overall metabolism $[8,9]$.

Currently, there is a number of studies to study the regularities of the effects of various physical activity on the balance of the POL-AO system in the body, poorly studied the peculiarities of the processes of POL in the body under the influence of physical activity, but there is no information about the relationship between the distribution of the concentration of enzymes of the POL-AO system in muscle tissue and blood serum.

Thus, the aim of our study was to study the relationship between the distribution of POL-AO enzyme concentrations in the blood serum and skeletal muscle tissue of white non-pedigreed rats. 
In order to achieve this goal, the following tasks had to be accomplished: to determine the concentration of catalase, superoxide dismutase (SOD), glutathione peroxidase (GP), glutathione reductase (GR), malonedialdehyde (MDA) and diene conjugates (DC) in blood serum and skeletal muscle tissue of white non-pedigreed rats; to reveal the correlation between the concentration distribution of enzymes of POL-AO system in blood serum and muscle tissue of rats.

\section{Materials and methods}

The study was carried out on white, non-patented, healthy male rats of the same month of birth, weighing 180-200 g, in the amount of 150 pieces, which were kept in the vivarium under standard conditions.

The research was carried out in accordance with the rules of laboratory practice in the Russian Federation: the order of the Ministry of Health of the USSR № 755 from 12.08.1977, the order of the Ministry of Health of the Russian Federation № 267 from 19.06.2003, the law «On the protection of animals from cruelty», Chapter V, Art. 104679GD from 01.12.1999.

Determination of catalase activity was carried out using the standard method of Korolyuk M.A. The activity of superoxide dismutase was determined by the method of V.S. Gurevich and co-authors. The activity of glutathione peroxidase was determined by the method of V.M. Moine. The activity of glutathione reductase and diene conjugates was determined spectrophotometrically at a wavelength of $340 \mathrm{~nm}$ and $233 \mathrm{~nm}$, respectively. The MDA concentration was determined by the V.V. method. Bogozhin [10].

Enzyme concentrations were studied in skeletal muscle tissue and blood serum. For this purpose, rats were ethically killed under etheric anesthesia by decapitation, then the skeletal muscle tissue was extracted, washed with saline solution and immediately frozen. Homogenates were prepared by mechanical crushing of $1 \mathrm{~g}$ of muscle tissue with $9 \mathrm{ml}$ of tris buffer ( $\mathrm{pH} 7.4$ ), at a rate of $5000 \mathrm{rpm}$ in a vessel with double walls, constantly cooled by running water [10].

Digital material was statistically processed by nonparametric Spearman correlation analysis, as well as by using gamma correlation coefficients and Kendella Tau.

\section{Results of the study}

As a result of experiments, an array of numerical concentrations of catalase, SOD, GP, GR, MDA and diene conjugates in blood serum and skeletal muscle tissue of white nonpedigreed rats was obtained. The results were statistically processed (Table 1). At the first stage of the statistical analysis we checked for compliance with the normal distribution of POL-AO enzyme concentrations in blood serum and rat muscle tissue. For this purpose Kolmogorov-Smirnov single-sample criterion was used. As a result, it was found that the distribution of POL-AO system enzymes concentration in blood serum and rat muscle tissue does not correspond to normal. In connection with that at the further statistical processing we applied nonparametric methods of analysis.

Table 1.Distribution of POL-AO enzyme concentrations in blood serum and skeletal muscle tissue of white non-pedigreed rats

\begin{tabular}{|c|c|c|c|c|c|c|c|c|c|}
\hline $\begin{array}{c}\text { Descriptive } \\
\text { statistics of } \\
\text { merged }\end{array}$ & $\mathrm{N}$ & $\mathrm{M}$ & $\mathrm{Me}$ & Min & Max & $\begin{array}{c}25 \\
\text { Perc }\end{array}$ & $\begin{array}{c}75 \\
\text { Perc }\end{array}$ & $\begin{array}{c}10 \\
\text { Perc }\end{array}$ & $\begin{array}{c}90 \\
\text { Perc }\end{array}$ \\
\hline
\end{tabular}




\begin{tabular}{|c|c|c|c|c|c|c|c|c|c|}
\hline groups & & & & & & & & & \\
\hline \multicolumn{10}{|c|}{ Catalase } \\
\hline Bloodserum & $\begin{array}{c}15 \\
0\end{array}$ & 19,72 & 19,60 & 17,40 & 22,10 & 18,90 & 20,40 & 18,35 & 21,40 \\
\hline $\begin{array}{l}\text { Skeletalmuscl } \\
\text { es }\end{array}$ & $\begin{array}{c}15 \\
0\end{array}$ & 35,20 & 35,20 & 33,10 & 37,40 & 34,50 & 35,80 & 33,70 & 36,45 \\
\hline \multicolumn{10}{|c|}{ Superoxidedismutase } \\
\hline Bloodserum & $\begin{array}{c}15 \\
0\end{array}$ & 29,01 & 29,10 & 27,30 & 30,70 & 28,40 & 29,60 & 28,00 & 30,20 \\
\hline $\begin{array}{l}\text { Skeletalmuscl } \\
\text { es }\end{array}$ & $\begin{array}{c}15 \\
0\end{array}$ & 96,96 & 96,80 & 94,80 & 98,90 & 96,30 & 97,70 & 95,60 & 98,45 \\
\hline \multicolumn{10}{|c|}{ Glutathioneperoxidase } \\
\hline Bloodserum & $\begin{array}{c}15 \\
0\end{array}$ & $\begin{array}{c}123,5 \\
0\end{array}$ & $\begin{array}{c}123,5 \\
0\end{array}$ & $\begin{array}{c}122,1 \\
0\end{array}$ & $\begin{array}{c}125,1 \\
0\end{array}$ & $\begin{array}{c}123,1 \\
0\end{array}$ & $\begin{array}{c}124,2 \\
0\end{array}$ & $\begin{array}{c}122,6 \\
0\end{array}$ & $\begin{array}{c}124,7 \\
0\end{array}$ \\
\hline $\begin{array}{l}\text { Skeletalmuscl } \\
\text { es }\end{array}$ & $\begin{array}{c}15 \\
0\end{array}$ & $\begin{array}{c}143,3 \\
0\end{array}$ & $\begin{array}{c}143,4 \\
0\end{array}$ & $\begin{array}{c}141,7 \\
0\end{array}$ & $\begin{array}{c}145,2 \\
0\end{array}$ & $\begin{array}{c}142,7 \\
0\end{array}$ & $\begin{array}{c}143,8 \\
0\end{array}$ & $\begin{array}{c}142,2 \\
0\end{array}$ & $\begin{array}{c}144,3 \\
5\end{array}$ \\
\hline \multicolumn{10}{|c|}{ Glutathionereductase } \\
\hline Bloodserum & $\begin{array}{c}15 \\
0\end{array}$ & 70,75 & $\mathbf{7 0 , 8 0}$ & 69,40 & 71,80 & 70,40 & 71,20 & 69,80 & 71,60 \\
\hline $\begin{array}{l}\text { Skeletalmuscl } \\
\text { es }\end{array}$ & $\begin{array}{c}15 \\
0\end{array}$ & 24,65 & 24,60 & 23,10 & 25,90 & 24,20 & 25,10 & 23,80 & 25,70 \\
\hline \multicolumn{10}{|c|}{ MaloneDialdehyde } \\
\hline Bloodserum & $\begin{array}{c}15 \\
0\end{array}$ & 6,31 & 6,35 & 5,30 & 7,90 & 5,90 & 6,70 & 5,70 & 6,90 \\
\hline $\begin{array}{l}\text { Skeletalmuscl } \\
\text { es }\end{array}$ & $\begin{array}{c}15 \\
0\end{array}$ & 5,86 & 5,80 & 5,10 & 6,70 & 5,60 & 6,20 & 5,30 & 6,40 \\
\hline \multicolumn{10}{|c|}{ Dieneconjugates } \\
\hline Bloodserum & $\begin{array}{c}15 \\
0\end{array}$ & 34,31 & 34,30 & 32,90 & 35,60 & 33,90 & 34,70 & 33,50 & 35,10 \\
\hline $\begin{array}{l}\text { Skeletalmuscl } \\
\text { es }\end{array}$ & $\begin{array}{c}15 \\
0\end{array}$ & 30,24 & 30,20 & 28,50 & 31,90 & 29,50 & 30,80 & 29,10 & 31,50 \\
\hline
\end{tabular}

In order to estimate the correlation between the concentration distribution of POL-AO enzymes in blood serum and skeletal muscles of small experimental animals, we studied the correlations within the observation group using the nonparametric Spearman correlation coefficient (Table 2), as well as using the gamma correlation coefficients and Kendella Tau (Table 3).

Table 2.Spearman correlation coefficient for the distribution of POL-AO enzyme concentration in blood serum and skeletal muscle tissue of rats and $\mathrm{p}$

\begin{tabular}{|l|l|c|c|c|}
\hline \multicolumn{1}{|c|}{ Enzyme } & $\begin{array}{c}\text { Spearman correlation } \\
\text { in all combined dimensions }\end{array}$ & ValidN & SpearmanR & p-level \\
\hline Catalase & Bloodserum\&muscle & $\mathbf{1 5 0}$ & $\mathbf{- 0 , 2 0 5 2 4 6}$ & $\mathbf{0 , 0 1 1 7 4 9}$ \\
\hline Superoxidedismutase & Bloodserum\&muscle & 150 & 0,011671 & 0,887281 \\
\hline Glutathioperoxidase & Bloodserum\&muscle & 150 & 0,074324 & 0,366039 \\
\hline Glutathionereductase & Bloodserum\&muscle & 150 & $-0,024625$ & 0,764856 \\
\hline MaloneDialdehyde & Bloodserum\&muscle & 150 & 0,025319 & 0,758424 \\
\hline Dieneconjugates & Bloodserum\&muscle & 150 & 0,022562 & 0,784048 \\
\hline
\end{tabular}


According to the data presented in Table 2, it is obvious that there is a weak force of reliable inverse correlation between the activity of catalase in blood serum and skeletal muscle tissue $(-0.21$ at $\mathrm{p} \leq 0.011749)$.

Since no correlation between the distribution of POL-AO enzyme concentrations in blood serum and rat skeletal muscles was found using the Spearman correlation coefficient, it was decided to perform an analysis using gamma correlation criteria and Kendella Tau (Table 3).

Table 3.Gamma and Kendella Tau correlation coefficients for the distribution of POL-AO enzyme concentrations in blood serum and skeletal muscle tissue in rats

\begin{tabular}{|c|c|c|c|c|c|}
\hline \multicolumn{6}{|c|}{$\begin{array}{l}\text { CorrelationGammaRatioCoefficient } \\
\end{array}$} \\
\hline \multicolumn{6}{|c|}{ MD pairwise deleted Marked correlations are significant at $\mathrm{p}<0,05000$} \\
\hline Enzyme & $\begin{array}{c}\text { Correlation in all } \\
\text { combined } \\
\text { dimensions }\end{array}$ & $\begin{array}{l}\text { Vali } \\
\text { d N }\end{array}$ & Gamma & $\mathbf{Z}$ & p-level \\
\hline Catalase & $\begin{array}{l}\text { Bloodserum\&muscl } \\
\text { e }\end{array}$ & 150 & $-0,144658$ & $-2,54344$ & $\begin{array}{c}0,01097 \\
7\end{array}$ \\
\hline $\begin{array}{l}\text { Superoxidedismutas } \\
\mathrm{e}\end{array}$ & $\begin{array}{l}\text { Bloodserum\&muscl } \\
\text { e }\end{array}$ & 150 & 0,009665 & $\begin{array}{c}0,16713 \\
9\end{array}$ & $\begin{array}{c}0,86726 \\
1\end{array}$ \\
\hline Glutathioperoxidase & $\begin{array}{l}\text { Bloodserum\&muscl } \\
\mathrm{e}\end{array}$ & 150 & 0,055708 & $\begin{array}{c}0,96635 \\
6\end{array}$ & $\begin{array}{c}0,33386 \\
6\end{array}$ \\
\hline Glutathionereductase & $\begin{array}{l}\text { Bloodserum\&muscl } \\
\text { e }\end{array}$ & 150 & $-0,022371$ & $\begin{array}{c}- \\
0,38099 \\
5\end{array}$ & $\begin{array}{c}0,70320 \\
7\end{array}$ \\
\hline MaloneDialdehyde & $\begin{array}{l}\text { Bloodserum\&muscl } \\
\text { e }\end{array}$ & 150 & 0,021870 & $\begin{array}{c}0,36795 \\
2\end{array}$ & $\begin{array}{c}0,71290 \\
9\end{array}$ \\
\hline Dieneconjugates & $\begin{array}{l}\text { Bloodserum\&muscl } \\
\text { e }\end{array}$ & 150 & 0,015628 & 0,26986 & $\begin{array}{c}0,78727 \\
0 \\
\end{array}$ \\
\hline \multicolumn{6}{|c|}{$\begin{array}{l}\text { Kendell Tau correlation coefficient } \\
\end{array}$} \\
\hline \multicolumn{6}{|c|}{ MD pairwise deleted Marked correlations are significant at $\mathrm{p}<, 05000$} \\
\hline Enzyme & $\begin{array}{c}\text { Correlation in all } \\
\text { combined } \\
\text { dimensions }\end{array}$ & $\begin{array}{l}\text { Valid } \\
\mathrm{N}\end{array}$ & $\begin{array}{c}\text { KendallTa } \\
\mathrm{u}\end{array}$ & $\mathrm{Z}$ & p-level \\
\hline Catalase & $\begin{array}{l}\text { Bloodserum\&muscl } \\
\mathrm{e}\end{array}$ & 150 & $-0,140064$ & $-2,54344$ & $\begin{array}{c}0,01097 \\
7 \\
\end{array}$ \\
\hline $\begin{array}{l}\text { Superoxidedismutas } \\
\mathrm{e}\end{array}$ & $\begin{array}{l}\text { Bloodserum\&muscl } \\
\text { e }\end{array}$ & 150 & 0,009204 & $\begin{array}{c}0,16713 \\
9 \\
\end{array}$ & $\begin{array}{c}0,86726 \\
1 \\
\end{array}$ \\
\hline Glutathioperoxidase & $\begin{array}{l}\text { Bloodserum\&muscl } \\
\text { e }\end{array}$ & 150 & 0,053216 & $\begin{array}{c}0,96635 \\
6 \\
\end{array}$ & $\begin{array}{c}0,33386 \\
6 \\
\end{array}$ \\
\hline Glutathionereductase & $\begin{array}{l}\text { Bloodserum\&muscl } \\
\text { e }\end{array}$ & 150 & $-0,020981$ & $\begin{array}{c}- \\
0,38099 \\
5 \\
\end{array}$ & $\begin{array}{c}0,70320 \\
7\end{array}$ \\
\hline MaloneDialdehyde & $\begin{array}{l}\text { Bloodserum\&muscl } \\
\text { e }\end{array}$ & 150 & 0,020263 & $\begin{array}{c}0,36795 \\
2 \\
\end{array}$ & $\begin{array}{c}0,71290 \\
9 \\
\end{array}$ \\
\hline Dieneconjugates & $\begin{array}{l}\text { Bloodserum\&muscl } \\
\mathrm{e}\end{array}$ & 150 & 0,014861 & 0,26986 & $\begin{array}{c}0,78727 \\
0 \\
\end{array}$ \\
\hline
\end{tabular}

According to the data presented in Table 3, it is evident that when studying the distribution of concentrations of enzymes of the POL-AO system in blood serum and 
skeletal muscle tissue of white rats the inverse reliable correlation of weak force between the concentration of catalase in blood serum and skeletal muscle tissue of rats was revealed: Gamma $=-0.14$ at $\mathrm{p} \leq 0.010977$; Kendall Tau $=-0.14$ at $\mathrm{p} \leq 0.010977$.

\section{Conclusions}

Thus, all three methods of nonparametric correlation analysis used to assess the relationship between the concentration distribution of enzymes of the POL-AO system in blood serum and skeletal muscles of rats SOD in serum revealed that the activity of catalase in rats within the physiological norm determines a reliable inverse correlation of weak force between the concentration of catalase in blood serum and skeletal muscle tissue

\section{References}

1. S.A. Aliyev, A.K. Hasanova, S.S. Alibekova, Scientific Almanac, 12-2 (14), 397-404 (2015)

2. Z.I. Mikashinovich, E.S. Belousova, Impairment of energy-dependant processes in the muscle tissue as a pathogenetic mechanisms of statininduced myopathy. Byulleten' eksperimental'noybiologiiimeditsiny, 162 (10), 426-430 (2016)

3. A.M. Hajiyev, S.A. Aliyev, S.E. Agaeva, Theory and practice of physical culture and sport, 8, 53-56 (2014)

4. E.V. Kalinina, N.N. Chernov, R. Aleid, et, Vestnik RAMN, 3, 46-54 (2010)

5. S.E. Agaeva, A.M. Hajiyev, S.A. Aliyev, Biomedical series. Tbilisi, 36(5- 6), 311-317 (2010)

6. M. Mittal, M.R. Siddiqui, K. Tran, S.P. Reddy, A.B. Malik Redox Signal, 20, 11261167 (2014)

7. A.K. Hasanova, S.A. Aliyev, G.M. Behbudova, Izv. Ped. University, 3, 412-419 (2013)

8. A.M. Hajiyev, S.A. Aliyev, S.E. Agaeva Theory and practice of physical culture and sport. Moscow, 8, 53-56 (2014)

9. J. Xu, F. Lupu, C. Esmon, Hamostaseol, 1, 30, 5-9 (2010)

10. D.I. Maksimovich, E.O. Korik, INTERNAUKA, 12-1 (16), 10-12 (2017) 